\title{
Response of Sorghum (Sorghum bicolor L.) extract type, concentration and application time to weeds weight, grain and biomass yield of Wheat
}

\author{
Abdul Rab ${ }^{1 *}$, Shad Khan Khalil ${ }^{1}$, Muhammad Asim², Nasir Mehmood ${ }^{3}$, \\ Hina Fayyaz ${ }^{4}$, Imran Khan ${ }^{1}$, Salman Zahid ${ }^{1}$ and Haq Nawaz ${ }^{1}$ \\ 1. Department of Agronomy, The University of Agriculture Peshawar-Pakistan \\ 2. Department of Agronomy, University of Agriculture Faisalabad-Pakistan \\ 3. Department of Plant Protection, The University of Agriculture Peshawar-Pakistan \\ 4. Directorate General Agricultural Research Peshawar, Khyber Pakhtunkhwa-Pakistan \\ *Corresponding author's email: abdulrab@aup.edu.pk \\ Citation \\ Abdul Rab, Shad Khan Khalil, Muhammad Asim, Nasir Mehmood, Hina Fayyaz, Imran Khan, Salman Zahid and \\ Haq Nawaz. Response of Sorghum (Sorghum bicolor L.) extract type, concentration and application time to weeds \\ weight, grain and biomass yield of Wheat. Pure and Applied Biology. Vol. 5, Issue 4, pp847-855. \\ http://dx.doi.org/10.19045/bspab.2016.50106
}

Received: 16/05/2016 Revised: 28/07/2016

Accepted: 06/08/2016

Online First: 13/08/2016

\section{Abstract}

High crop yield depend upon effective weeds control through commercial herbicides. However, use of commercial herbicides may pollute environment and underground water. Toxicity and resistance development against commercial herbicides demand for exploring alternative methods for weeds control. Aim of this study was to evaluate effect of sorghum water extract on weeds weight and yield of wheat cultivar "Atta Habib 2010". Research was conducted at Agronomy Research Farm, University of Agriculture Peshawar in 2014-15. Sorghum stem (SS) and leaf (SL) extracts with three concentrations $\left(1: 3,1: 4\right.$ and $\left.1: 5 \mathrm{~kg} \mathrm{~L}^{-1}\right)$ and three application time (emergence, tillering and $50 \%$ at emergence +50 at tillering) were used. Herbicides $(\mathrm{H})$ treated, hand weeding $(\mathrm{HW})$ and unweeded plots were included for comparison. $\mathrm{H}$ treated plots produced less weeds weight $\left(128.3 \mathrm{~g} \mathrm{~m}^{-2}\right)$, higher leaf area index (LAI) (4.0), more spikes $\mathrm{m}^{-2}$ (350), heavier thousand grains $(51 \mathrm{~g})$ and more biomass yield (BY) (10333 $\left.\mathrm{kg} \mathrm{ha}^{-1}\right)$ compared to sorghum water extract sprayed plots. Among concentrations (C), sorghum water extracts sprayed at 1:3 concentration gave lower weeds weight $\left(257 \mathrm{~g} \mathrm{~m}^{-2}\right)$, more LAI (3.4), more spikes $\mathrm{m}^{-2}$ (320) heavier thousand grains (46 g) and higher BY (9789 $\mathrm{kg} \mathrm{ha}^{-1}$ ). Amongst application time (AT), sorghum water extracts applied at tillering resulted in low weeds weight $\left(256 \mathrm{~g} \mathrm{~m}^{-2}\right)$, higher LAI (3.2), more spikes $\mathrm{m}^{-2}$ (315), higher thousand grains (45 g) and more BY (9621 kg ha-1). SL extracts gave less weeds weight $\left(269 \mathrm{~g} \mathrm{~m}^{-2}\right)$, more LAI (3.2), more spikes m${ }^{-2}$ (314), heavier thousand grains (45 g) and higher BY (9576 kg ha-1) compared with SS extracts. It is concluded that leaf water extract applied at tillering with 1:3 concentration reduced weeds weight and increased thousand grain weight of wheat and is recommended for suppressing weeds weight and enhancing thousand grain weight of wheat in agro climatic conditions of Peshawar.

Keywords: Sorghum stem \& leaf extracts; Weeds weight; Leaf area index; Biomass; Wheat 


\section{Introduction}

Wheat (Triticum aestivum) is a major cereal crop, grown on irrigated and rainfed regions in Pakistan [1]. It was planted on 9.1 million ha area with production of 25.9 million tons having an average yield of 2.82 tons $\mathrm{ha}^{-1}$ in Pakistan [2]. Wheat yield is very low compared with other wheat producing countries of the world [2]. Amongst other factors reducing wheat yield, weeds infestation is the main but less identified constraint in Pakistan [3]. Weeds are unwanted plants and most universal pest which share nutrients, light, moisture, space and carbon dioxide with crops [4]. Major infesting weeds of wheat fields in Pakistan are field bindweed (Convolvulus arvensis), wild oat (Avena fatua), canary grass (Phalaris minor), annual bluegrass (Poa annua), broad leaf dock (Rumax dentatus), lambsquarters (Chenopodium album), and Canada thistle (Cirsium arvense) [5]. About $25 \%$ losses due to weeds infestation have been reported worth Rs. 120 billions [6], while wheat only accounts for Rs 30 billion [7].

Modern farming is yield oriented and mostly depends on synthetic chemicals for reducing weeds. However, injudicious application of synthetic herbicides resulted in many problems such as underground water pollution, health and environmental hazards [8]. Sorghum being a potential allelopathic crop contains many allelochemicals that reduces weeds growth [9]. Different secondary metabolites such as phenolics, flavonoids, alkaloids and terpeniods were observed in sorghum herbage [10]. Phenolics compounds identified in sorghum are benzoic acid, caffeic acid, coumaric acid, syringic acids, gallic acid, chlorogenic acid and ferulic acid [11]. These phenolics compounds are considered as phytotoxic and they suppressed density and growth of weeds [12].
Though sorghum water extract is a cheap and environment friendly technology, however its effectiveness to reduce weeds density is beyond the desired level of weed reduction (80\%). Foliar application of sorghum water extract reduced weed density and dry weeds weight by 15 to $17 \%$ and 19 to $49 \%$ respectively [13]. In low quantity allelochemicals showed stimulatory effect, whereas in high amount allelochemicals proved inhibitory reaction toward weeds germination and weeds growth [14]. Keeping in view the importance of huge losses caused by weeds in wheat the present study was therefore undertaken to investigate the effects of sorghum extract type, concentration and application time on weeds weight, grain and biomass yield of wheat in agro-climatic conditions of Peshawar valley.

\section{Materials and methods}

Field experiment was conducted at Agronomy Research Farm, The University of Agriculture Peshawar, Pakistan during Rabi season 2014-15 with randomized completely block design replicated thrice. A plot size of $5.4 \mathrm{~m}^{2}(3 \times 1.8 \mathrm{~m})$ having six rows three meter long with $30 \mathrm{~cm}$ apart rows were used. Atta Habib-2010 wheat cultivar with seed rate of $120 \mathrm{~kg} \mathrm{ha}^{-1}$ was planted on $27^{\text {th }}$ November2014 as a test crop with the help of seed drill and was harvested on $15^{\text {th }}$ May 2015 with the help of hand sickle. A basic dose of $120 \mathrm{~kg}$ nitrogen $(\mathrm{N})$ and $90 \mathrm{~kg}$ phosphorus $(\mathrm{P})$ were applied using Urea and DAP (di ammonium phosphate) as source of $\mathrm{N}$ and $\mathrm{P}$. All the $\mathrm{P}\left(\mathrm{P}_{2} \mathrm{O}_{5}\right)$ and half of $\mathrm{N}$ were applied at sowing and the remaining half of $\mathrm{N}$ was applied with first irrigation. Sorghum stem and leaf water extract was applied as foliar spray with knapsack hand sprayer over weeds. No weeds check was performed and no spray was applied in control plots. Manual hand weeding was done by uprooting the weeds in hand weeded plots. Post emergence herbicides Buctril super 
60EC (bromoxynil+MCPA) @ $1.5 \mathrm{~L} \mathrm{a.i} \mathrm{ha}^{-1}$ and Puma Super 75EW (fenoxaprop-Pethyl)@1.25 L a.i ha ${ }^{-1}$ were applied 45 days after sowing in herbicides treated plots as broad leaf and narrow leaf weedicides respectively. Rest of the agronomic and cultural practices were kept uniform for all experimental units. The experiment was composed of following three factors.

\section{A) Sorghum extract type (SET)}

i. Leaf water extract (LWE)

ii. Stem water extract (SWE)

B) Extract concentration $(\mathrm{C})\left(\mathrm{kg} \mathrm{L}^{-1}\right)$

i. $\mathrm{C}_{1}=1: 3$

(1 kg sorghum herbage in 3 liters of water)

ii. $\mathrm{C}_{2}=1: 4$

(1 kg sorghum herbage in 4 liters of water)

iii. $\mathrm{C}_{3}=1: 5$

(1 $\mathrm{kg}$ sorghum herbage in 5 liters of water)

C) Application time (AT)

i. $\mathrm{AT}_{1}=$ Emergence $(\mathrm{E})$

ii. $\mathrm{AT}_{2}=$ Tillering $(\mathrm{T})$

iii. $\mathrm{AT}_{3}=50 \%$ at $\mathrm{E}+50 \%$ at $\mathrm{T}$

\section{Sorghum water extract preparation}

Mature sorghum plants were collected from Agronomy Research Farm, The University of Agriculture Peshawar, Pakistan. The stem and leaf herbage of these plants were separated and sun dried for few days. Sun dried stems and leaves were chopped into 2$3 \mathrm{~cm}$ pieces with electric fodder chopper machine separately and stored under shade to avoid possible leaching by rainfall. Chopped stem and leaf herbage were separately soaked in distilled water in 1:3 (1 $\mathrm{kg}$ each of stem and leaf herbage and 3 liters water), in separate container for 36 hours at room temperature. The mixture (sorghum herbage and water) was sieved through muslin cloth to remove sorghum crop herbage and to obtain the respective stem and leaf water extract of sorghum. These extract were diluted with distilled water to prepare other concentrations (1:4 and $1: 5 \mathrm{~kg}$ $\mathrm{L}^{-1}$ ) of stem and leaf extract according to the treatments. Fresh leaf and stem water extract were prepared for each application time.

Treatments were applied in the following combinations.

$\mathrm{T}_{1}=$ Control (No weed check and no spray)

$\mathrm{T}_{2}=$ Hand weeding (Manual hand weeding by uprooting weeds)

$\mathrm{T}_{3}=$ Herbicides application (Buctril Super

@ 1.5 L ha $\mathrm{L}^{-1}$ and Puma Super @ 1.25 $\mathrm{L} \mathrm{ha}^{-1}$ )

$\mathrm{T}_{4}=\mathrm{LWE} @ 1: 3$ applied at emergence $(\mathrm{E})$

$\mathrm{T}_{5}=$ LWE @ 1:3 applied at tillering (T)

$\mathrm{T}_{6}=\mathrm{LWE} @ 1: 3$ applied $50 \%$ at $\mathrm{E}+50 \%$ at $\mathrm{T}$

$\mathrm{T}_{7}=\mathrm{LWE} @ 1: 4$ applied at emergence $(\mathrm{E})$

$\mathrm{T}_{8}=\mathrm{LWE} @ 1: 4$ applied at tillering $(\mathrm{T})$

$\mathrm{T}_{9}=\mathrm{LWE} @ 1: 4$ applied $50 \%$ at E + 50\% at $\mathrm{T}$

$\mathrm{T}_{10}=\mathrm{LWE} @ 1: 5$ applied at emergence $(\mathrm{E})$

$\mathrm{T}_{11}=\mathrm{LWE} @ 1: 5$ applied at tillering $(\mathrm{T})$

$\mathrm{T}_{12}=\mathrm{LWE} @ 1: 5$ applied $50 \%$ at E + $50 \%$ at $\mathrm{T}$

$\mathrm{T}_{13}=$ SWE @ 1:3 applied at emergence $(\mathrm{E})$

$\mathrm{T}_{14}=\mathrm{SWE} @ 1: 3$ applied at tillering $(\mathrm{T})$

$\mathrm{T}_{15}=\mathrm{SWE} @ 1: 3$ applied $50 \%$ at $\mathrm{E}+50 \%$ at $\mathrm{T}$

$\mathrm{T}_{16}=$ SWE @ 1:4 applied at emergence $(\mathrm{E})$

$\mathrm{T}_{17}=\mathrm{SWE} @ 1: 4$ applied at tillering $(\mathrm{T})$

$\mathrm{T}_{18}=\mathrm{SWE} @ 1: 4 \operatorname{applied} 50 \%$ at E + 50\% at $\mathrm{T}$

$\mathrm{T}_{19}=\mathrm{SWE} @ 1: 5$ applied at emergence $(\mathrm{E})$

$\mathrm{T}_{20}=\mathrm{SWE} @ 1: 5$ applied at tillering $(\mathrm{T})$

$\mathrm{T}_{21}=\mathrm{SWE} @ 1: 5$ applied $50 \%$ at E + 50\% at $\mathrm{T}$.

\section{Data measurements}

Data were recorded by using standard methods according to weeds fresh weight, leaf area index, spikes $\mathrm{m}^{-2}$, thousand grains weight and biomass yield. For obtaining data on fresh weight of weeds the number of weeds in a meter row at two separate spots were uprooted, cleaned and weighed with digital balance to record fresh weight of weeds in gram $\mathrm{m}^{-2}$. Weeds fresh weight data was recorded two times (i.e. 70 and 90 days after sowing) in each plot and then averaged for further analysis. Leaf area index (LAI) 
data was calculated by using the given formula.

LAI $=\underline{\text { Leaf area tiller }}{ }^{-1}$ Ground area tiller ${ }^{-1}$

Data regarding spikes $\mathrm{m}^{-2}$ was recorded by counting the number of spikes in one meter row at two separate spots randomly in each plot and then averaged. The equation used for calculating spikes $\mathrm{m}^{-2}$ was as under. Spikes $\mathrm{m}^{-2}=\underline{\text { Spikes counted in a meter row }}$ $0.3 \mathrm{~m} \times 1 \mathrm{~m} \mathrm{x} 1$

For thousand grain weight data, weight of two representative samples of thousand grains were obtained from each experimental unit at random and then averaged. Seeds were counted with electronic seed counter machine and weighed with electric balance to recorded 1000 grain weight in grams (g). For biomass yield data three middle rows were harvested manually with the help of sickle. The harvested rows were bundled, tied and sun dried for some days. The total weight in kilograms of sun dried bundles were calculated and converted into biomass yield $\mathrm{kg} \mathrm{ha}^{-1}$ by applying the given equation.

Biomass $=\underline{\text { Central three rows biomass }} \times 10000$

$$
0.3 \mathrm{~m} \mathrm{x} 3 \mathrm{~m} \mathrm{x} 3
$$

\section{Statistical analysis}

Data were statistically analyzed according to the procedure described by [15] for randomized complete block design and means were separated by least significant differences test $(\mathrm{P}<0.05)$ upon significant $\mathrm{F}$ test.

\section{Results and discussions Weeds fresh weight $\left(\mathrm{g} \mathrm{m}^{-2}\right)$}

Sorghum extract type, concentration and application time significantly affected weeds fresh weight of wheat, whereas all the interactions were non-significant (Table 1). Herbicides sprayed plots produced less weeds weight (128.3 $\mathrm{g} \mathrm{m}^{-2}$ ) compared with sorghum water extract (SWE) sprayed plots (276.0 $\mathrm{g} \mathrm{m}^{-2}$ ) (Table 2). Similarly, hand weeded plots and SWE sprayed plots resulted in lower weeds weight $\left(165.0 \mathrm{~g} \mathrm{~m}^{-2}\right)$ compared with control plots $\left(451.7 \mathrm{~g} \mathrm{~m}^{-2}\right)$. Mean values for sorghum extract type showed that leaf water extract produced lower weeds weight $\left(268.5 \mathrm{~g} \mathrm{~m}^{-2}\right)$ compared with stem water extract $\left(283.4 \mathrm{~g} \mathrm{~m}^{-2}\right)$. Mean values for concentration showed that lower weeds weight $\left(257.4 \mathrm{~g} \mathrm{~m}^{-2}\right)$ was produced with 1:3 concentration while, more weeds weight $\left(296.5 \mathrm{~g} \mathrm{~m}^{-2}\right)$ was obtained with 1:5 concentration. Application time indicated that SWE applied at tillering gave lower weeds weight $\left(255.7 \mathrm{~g} \mathrm{~m}^{-2}\right)$, while SWE applied $50 \%$ at emergence $+50 \%$ at tillering resulted in more weeds weight $\left(295.0 \mathrm{~g} \mathrm{~m}^{-2}\right)$. Minimum weeds weight in herbicides treated and hand weeded plots may be due to the lower weeds recorded in herbicides treated and hand weeded plots. These results are in line with $[1,16,17]$ who reported that herbicides treatments were most effective in weeds control. Concentrated extract reduced weed density, which ultimately resulted in lower weeds weight. Our results are in line with $[14,18$, 19] who concluded that lower concentration of SWE exhibit stimulatory effects on growth and germination of some weeds while higher concentration exhibit inhibitory effects on their germination. Similar results were reported by $[1,17,20]$ who observed lower weeds weight by 25, 22 and $42 \%$ respectively with $\mathrm{SWE}$ foliar application.

\section{Leaf area index}

Sorghum extract type, concentration and application time significantly affected leaf area index (LAI) of wheat, whereas all the interactions were non-significant (Table 1). Herbicides sprayed plots produced more LAI (4.02) compared with sorghum water extract sprayed plots (3.17) (Table 2). Similarly, hand weeded plots and SWE sprayed plots resulted in higher LAI (3.75) compared with control plots (1.92). Mean values for concentration showed that high LAI (3.35) was produced with 1:3 
concentrations. LAI decreased with each increase in concentration and lower LAI (3.00) was recorded with 1:5 concentrations. SWE applied at tillering gave more LAI (3.23), whereas SWE applied $50 \%$ at emergence $+50 \%$ at tillering resulted in less LAI (3.11). Leaf water extract produced higher LAI (3.20) compared with stem water extract (3.14). Significant increase in LAI with herbicides application, HW and sorghum extract sprays may be attributed to production of greater leaf area in herbicides treated, hand weeded and SWE sprayed plots respectively. These results are in line with [21-24] who reported significant increased in LAI with application of SWE and herbicides.

\section{Spikes $\mathbf{m}^{-2}$}

Sorghum extract type, concentration and application time significantly affected spike $\mathrm{m}^{-2}$ of wheat, whereas all the interactions were non-significant (Table 1). Herbicides sprayed plots gave more spikes $\mathrm{m}^{-2}$ (350.3) compared with SWE sprayed plots (312.6) (Table 2). Similarly, hand weeded plots and SWE sprayed plots produced more spikes $\mathrm{m}^{-}$ 2 (342.3) compared with control plots (259.3). Mean values for concentration showed that fewer spikes $\mathrm{m}^{-2}$ (305.4) were noted with 1:5 concentrations. Spikes $\mathrm{m}^{-2}$ increased with each decrease in concentration and more spikes $\mathrm{m}^{-2}$ (320.1) were recorded with $1: 3$ concentrations. SWE applied at tillering produced more spikes $\mathrm{m}^{-2}$ (315.2), whereas SWE sprayed $50 \%$ at emergence $+50 \%$ at tillering gave less spikes $\mathrm{m}^{-2}$ (310.2). Leaf water extract gave more spikes $\mathrm{m}^{-2}$ (313.8) compared with stem water extract (311.3). The greater number of spikes $\mathrm{m}^{-2}$ with herbicides application might be due to the high phytotoxic effect of herbicides on weeds, while the lower number of spikes $\mathrm{m}^{-2}$ with SWE spray may be attributed to their less phytotoxic effect on weeds as compared with herbicides. The least number of spikes in control plots might be due to higher weed competition of wheat plant with weeds for resources i.e. nutrients, water, space and light etc. These results are in line with $[16,25,26]$ who reported significant increase in spikes $\mathrm{m}^{-2}$ of wheat with $\mathrm{H}$ application and allelopathic leaf water extract of different plants.

\section{Thousand grain weight (g)}

Sorghum extract type, concentration and application time significantly affected thousand grain weight of wheat, whereas all the interactions were non-significant (Table 1). Herbicides sprayed plots produced more thousand grain weight (50.7 g) compared with SWE sprayed plots (44.5 g) (Table 2). Likewise, hand weeded plots and SWE sprayed plots resulted in heavier thousand grain weight (49.0 g) compared with control plots $(38.0 \mathrm{~g})$. Mean values for concentration showed that more thousand grain weight $(46.3 \mathrm{~g})$ was resulted with $1: 3$ concentration. Thousand grain weight of wheat decreased with each increase in concentration and less thousand grains weight (46.3 g) was recorded when with 1:5 concentration. SWE sprayed at tillering gave more thousand grain weight $(45.2 \mathrm{~g})$, which is statistically at par with SWE applied at emergence resulted in (44.7 g) thousand grain weight of wheat, while less thousand grain weight (43.5 g) was recorded with SWE applied as $50 \%$ at emergence $+50 \%$ tillering. Leaf water extract resulted in more thousand grain weight (44.8 g) compared with stem water extract $(44.2 \mathrm{~g})$. The possible reason for higher thousand grain yield with herbicides application, HW and SWE spray might be due to the less competition of wheat plants with weeds for nutrients and other resources like light, water and space in these plots and may enhanced the exploitation of nutrients and resources from soil which ultimately produced heavier grains of wheat. Lower thousand grain weight in control plots might be due to the more competition of wheat 
crop with weeds for resources like nutrients, moisture, and light etc. These results are line with the findings of $[1,13,27]$ who reported that herbicides treated plots produced heavier grains weight of wheat than hand weeding and SWE. Heavier grains were also reported by $[17,28,29]$ with SWE compared with unweeded.

\section{Biomass yield (kg ha ${ }^{-1}$ )}

Sorghum extract type, concentration and application time significantly influenced biomass yield of wheat, whereas all the interactions were non-significant (Table 1). Herbicides sprayed plots gave heavier biomass yield (10333.3 $\mathrm{kg} \mathrm{ha}^{-1}$ ) compared with SWE sprayed plots (9653.4 $\mathrm{kg} \mathrm{ha}^{-1}$ ) (Table 2). Similarly, hand weeded plots and SWE sprayed plots produced more biomass yield (10040.0 kg ha-1) compared with control plots $\left(7766.7 \mathrm{~kg} \mathrm{ha}^{-1}\right)$. Mean values for concentration showed that higher biomass yield ( $9788.9 \mathrm{~kg} \mathrm{ha}^{-1}$ ) was recorded with 1:3 concentrations. Biomass yield of wheat decreased with each increase in concentration and less biomass yield (9250.0 $\mathrm{kg} \quad \mathrm{ha}^{-1}$ ) was recorded with 1:5 concentrations. SWE sprayed at tillering gave more biomass yield (9620.6 kg ha-1), while SWE applied $50 \%$ at emergence +50 $\%$ tillering gave lower biomass yield $\left(9448.9 \mathrm{~kg} \mathrm{ha}{ }^{-1}\right)$. Leaf water extract produced more biomass yield $\left(9576.3 \mathrm{~kg} \mathrm{ha}^{-}\right.$ $\left.{ }^{1}\right)$ compared with stem water extract $(9488.5$ $\left.\mathrm{kg} \mathrm{ha}{ }^{-1}\right)$. The higher biomass yield with herbicides application, HW and SWE spray might be due to the reduced weed density in these plots which enhanced wheat growth and produced more tillers and spikes $\mathrm{m}^{-2}$, heighted plants and more leaf area tiller ${ }^{-1}$ etc and thus resulted in overall increase in biomass yield. The lower biomass yield in control plots may be attributed to the least number of tiller $\mathrm{m}^{-2}$ due to higher weed density and more competition of wheat crop with weeds for resources. These results are in line with the findings of $[24,26,30,31]$ who reported higher biomass yield with herbicides and allelopathic water extract foliar application compared with control.

Table 1. Mean square for weeds fresh weight, leaf area index, spikes $\mathbf{~ m}^{-2}$, thousand grains weight and biomass yield of wheat as affected by Sorghum extract type, concentration and application time

\begin{tabular}{|c|c|c|c|c|c|c|}
\hline $\begin{array}{l}\text { Source of variation } \\
\text { (SOV) }\end{array}$ & $\begin{array}{l}\text { Degree of } \\
\text { freedom }\end{array}$ & $\begin{array}{l}\text { Weeds weight } \\
\left(\mathrm{g} \mathrm{m}^{-2}\right)\end{array}$ & $\begin{array}{l}\text { Leaf area } \\
\text { index }\end{array}$ & $\begin{array}{l}\text { Number of } \\
\text { spikes }\left(\mathbf{m}^{-2}\right)\end{array}$ & $\begin{array}{l}\text { Thousand } \\
\text { grain weight (g) }\end{array}$ & $\begin{array}{l}\text { Biomass yield } \\
\left(\mathrm{kg} \mathrm{ha}^{-1}\right)\end{array}$ \\
\hline Replications & 2 & 267 & 0.000 & 18.2 & 3.0 & 22011 \\
\hline Treatments & $\{20\}$ & $11436 * *$ & $0.459 * *$ & $878 * *$ & $23.8 * *$ & $751885 * *$ \\
\hline $\begin{array}{l}\text { Sorghum Extract type } \\
\text { (SET) }\end{array}$ & $(1)$ & $2889 * *$ & $0.054 * *$ & $83 * *$ & $5.0 *$ & $104016 * *$ \\
\hline Extract Concentration (C) & (2) & $6659 * *$ & $0.561 * *$ & $977.8 * *$ & $72.3 * *$ & $1315879 * *$ \\
\hline Application Time (AT) & (2) & $8889 * *$ & $0.064 * *$ & $126.7 * *$ & $13.1 * *$ & $132902 * *$ \\
\hline SET x C & (2) & $0.462 \mathrm{NS}$ & $0.000 \mathrm{NS}$ & $4.019 \mathrm{NS}$ & $0.17 \mathrm{NS}$ & $2205 \mathrm{NS}$ \\
\hline SET x AT & (2) & $6.018 \mathrm{NS}$ & $0.000 \mathrm{NS}$ & $0.130 \mathrm{NS}$ & $0.02 \mathrm{NS}$ & $505 \mathrm{NS}$ \\
\hline $\mathrm{C} \times \mathrm{AT}$ & (4) & $0.462 \mathrm{NS}$ & $0.002 \mathrm{NS}$ & $7.546 \mathrm{NS}$ & $0.15 \mathrm{NS}$ & $2193 \mathrm{NS}$ \\
\hline SET x C x AT & (4) & $0.463 \mathrm{NS}$ & $0.000 \mathrm{NS}$ & $0.435 \mathrm{NS}$ & $0.06 \mathrm{NS}$ & $219 \mathrm{NS}$ \\
\hline $\begin{array}{l}\text { Hand weeding } \mathrm{x} \text { Sorghum } \\
\text { water extract }\end{array}$ & (1) & $36089 * *$ & $0.972 * *$ & $2338.6 * *$ & $58.2 * *$ & $732269 * *$ \\
\hline $\begin{array}{l}\text { Herbicides applications } \mathrm{x} \\
\text { Sorghum water extract }\end{array}$ & (1) & $63396 * *$ & $2.050 * *$ & $4036 * *$ & $108.9 * *$ & $1823160 * *$ \\
\hline $\begin{array}{l}\text { Control x Sorghum water } \\
\text { Extracts }\end{array}$ & (1) & $86029 * *$ & $4.441 * *$ & $8078 * *$ & $119.2 * *$ & $8861230 * *$ \\
\hline Error & 40 & 60.8 & 0.004 & 6.4 & 1.22 & 8506 \\
\hline Total & 62 & & & & & \\
\hline
\end{tabular}

$*=$ Significant at $5 \%$ level of probability, $* *=$ Significant at $1 \%$ level of probability, NS = Non-significant 
Table 2. Shows mean values for weeds fresh weight $\left(\mathrm{g} \mathrm{m}^{-2}\right)$, leaf area index, spikes $\mathbf{m}^{-2}$, thousand grains weight (g) and biomass yield $\left(\mathrm{kg} \mathrm{ha}^{-1}\right)$ of Wheat as affected by Sorghum extract type, concentration and application time

\begin{tabular}{|c|c|c|c|c|c|}
\hline Treatments & $\begin{array}{l}\text { Weeds } \\
\text { weight } \\
\left(\mathrm{g} \mathrm{m}^{-2}\right)\end{array}$ & $\begin{array}{l}\text { Leaf area } \\
\text { index }\end{array}$ & $\begin{array}{c}\text { Number } \\
\text { of spikes } \\
\left(\mathbf{m}^{-2}\right)\end{array}$ & $\begin{array}{c}\text { Thousand } \\
\text { Grains } \\
\text { weight (g) }\end{array}$ & $\begin{array}{c}\text { Biomass } \\
\text { yield } \\
\left(\mathrm{kg} \mathrm{ha}^{-1}\right)\end{array}$ \\
\hline \multicolumn{6}{|c|}{ Sorghum Extract Type (SET) } \\
\hline Leaf water extract & 268.5 & 3.20 & 313.9 & 44.8 & 9576.3 \\
\hline Stem water extract & 283.4 & 3.14 & 313.9 & 44.2 & 9488.5 \\
\hline \multicolumn{6}{|c|}{ Extract Concentration $(\mathrm{C})\left(\mathrm{kg} \mathrm{L}^{-1}\right)$} \\
\hline $1: 3$ & $257.4 \mathrm{c}$ & $3.35 \mathrm{a}$ & $320.2 \mathrm{a}$ & $46.3 \mathrm{a}$ & $9788.9 \mathrm{a}$ \\
\hline $1: 4$ & $274.0 \mathrm{~b}$ & $3.16 \mathrm{~b}$ & $312.2 \mathrm{~b}$ & $44.8 \mathrm{~b}$ & $9558.3 \mathrm{~b}$ \\
\hline $1: 5$ & $296.5 \mathrm{a}$ & $3.00 \mathrm{c}$ & $305.5 \mathrm{c}$ & $42.3 \mathrm{c}$ & $9250.0 \mathrm{c}$ \\
\hline $\operatorname{LSD}_{(0.05)}$ & 16.1 & 0.043 & 1.71 & 0.74 & 62.13 \\
\hline \multicolumn{6}{|l|}{ Application Time (AT) } \\
\hline Emergence $(\mathrm{E})$ & $277.2 \mathrm{~b}$ & $3.17 \mathrm{~b}$ & $312.3 \mathrm{~b}$ & $44.7 \mathrm{a}$ & $9527.8 \mathrm{~b}$ \\
\hline Tillering $(\mathrm{T})$ & $255.7 \mathrm{c}$ & $3.23 \mathrm{a}$ & $315.4 \mathrm{a}$ & $45.2 \mathrm{a}$ & $9620.6 \mathrm{a}$ \\
\hline $50 \%$ at $\mathrm{E}+50 \%$ at $\mathrm{T}$ & $295.0 \mathrm{a}$ & $3.11 \mathrm{c}$ & $310.2 \mathrm{c}$ & $43.5 \mathrm{~b}$ & $9448.9 \mathrm{c}$ \\
\hline $\operatorname{LSD}_{(0.05)}$ & 16.1 & 0.043 & 1.71 & 0.74 & 62.13 \\
\hline \multicolumn{6}{|c|}{ Planned Mean Comparison } \\
\hline Control & 451.7 & 1.92 & 259.3 & 38.0 & 7766.7 \\
\hline Sorghum water extract & 276.0 & 3.17 & 312.6 & 44.5 & 9532.4 \\
\hline Hand weeding & 165.0 & 3.75 & 341.3 & 49.0 & 10040.0 \\
\hline Herbicides application & 128.3 & 4.02 & 350.3 & 50.7 & 10333.3 \\
\hline \multicolumn{6}{|l|}{ Interactions } \\
\hline SET x C & NS & NS & NS & NS & NS \\
\hline SET x AT & NS & NS & NS & NS & NS \\
\hline $\mathrm{C} \times \mathrm{AT}$ & NS & NS & NS & NS & NS \\
\hline SET x C x AT & NS & NS & NS & NS & NS \\
\hline
\end{tabular}

Means of the same category followed by different letter (s) are significantly different at $\mathrm{P} \leq 0.05$ level using LSD test. $\mathrm{NS}=$ Non-Significant

\section{Conclusion}

It is concluded that sorghum leaf water extract applied with 1:3 concentration sprayed at tillering reduced weeds weight and produced heavier grains of wheat.

\section{Authors' contributions}

Conceived and designed the experiments: SK Khalil \& A Rab, Performed the experiments: A Rab, I Khan, M Asim, H Nawaz \& S Zahid, Analyzed the data: A Rab \& SK Khalil, Contributed reagents/ materials/ analysis tools: M Asim, I Khan, $\mathrm{H}$ Fayyaz, H Nawaz \& N Mehmood, Wrote the paper: A Rab \& SK Khalil.

\section{References}

1. Hussain S, Hassan F, Rasheed M, Ali S, \& Ahmad M (2014). Effects of allelopathic crop water extracts and their combinations on weeds and yield of rainfed wheat. $J$ of Food Agri \& Envin 12(3-4): 161-167. 
2. MNFSR (2014). Ministry of National Food Security and Research, Agricultural Statistics, Economic Wing, Government of Pakistan, Islamabad. Available at: http://www.mnfsr.gov.pk.

3. Qureshi R \& Bhatti GR (2001). Determination of weed communities in wheat (Triticum aestivum L.) fields of district Sukkur. Pakistan J Bot 33(1): 109-115.

4. Ozturk M, Kebapci U, Gucel S, Cetin E \& Altundag E (2012). Biodiversity and land degradation in the lower Euphrates sub region of Turkey. J Environ Biol 33: 311-323.

5. Hussain Z, Marwat KB, Munsif F, Samad A \& Ali K (2013). Evaluation of various herbicides and their combinations for weed control in wheat crop. Pakistan $J$ Bot. 45(1): 55-59.

6. Majeed A, Chaudhry Z \& Muhammad Z (2012). Allelopathic assessment of fresh aqueous extracts of Chenopodium album L. for growth and yield of wheat (Triticum aestivum L.) Pakistan J Bot 44 (1): 165-167.

7. Afridi RA (2014). Allelopathic effect of some plants and their potential as bioherbicides in combination with low rate of herbicides in wheat. Ph.D. Dissertation, Department of Weed Science, University of Agriculture Peshawar, Pakistan.

8. Farooq M, Jabran K, Cheema ZA, Wahid A \& Siddique KHM (2011). Exploiting allelopathy for sustainable agriculture. Pest Manag Sci 67: 493-506.

9. Jabran K, Cheema ZA, Farooq M \& Hussain M (2010). Lower doses of pendimethalin mixed with allelopathic crop water extracts for weed management in canola (Brassica napus). Int J Agric Biol 12: 335-340.

10. Jabran K \& Farooq M (2012). Implications of potential allelopathic crops in agricultural systems. In:
Allelopathy: Current Trends and Future Applications, pp: 349-385.

11. Hassan MM, Daffalla HM, Yagoub SO, Osman MG, Gani AME \& Babiker AGE (2012). Allelopathic effects of some botanical extracts on germination and seedling growth of Sorghum bicolor L. Int J of Agri Tech. 8(4):1423-1469.

12. Tesio F \& Ferrero A (2010). Allelopathy a chance for sustainable weed management. Int. J. Sustain. Develop. World Ecol. 17 (5): 377-389.

13. Cheema ZA \& Khaliq A (2000). Use of sorghum allelopathic properties to control weeds in irrigated wheat in a semi arid region of Punjab. Agric Ecos Environ. 79: 105-112.

14. Ghafarbi SP, Hassannejad S \& Lotfi R (2012). Allelopathic effects of wheat seed extracts on seed and seedling growth of eight selected weed species. Int J of Agric Crop Sci 4(19):14521457.

15. Steel RGD, Torrie JH \& Deekey DA (1997) Principles and Procedure of Statistics: A Biometrical Approach, 3rd edition, pp: 400-428. McGraw Hill Book Co. Inc. New York, USA.

16. Noor K, Khan EA, Baloch MS, Khan MA, Ullah I, Sadiq M \& Aslam M (2012). Allelopathic effect of congress grass on weeds and yield of wheat. Pakistan J Weed Sci Res 18(3): 307318.

17. Cheema ZA, Sadiq HMI \& Khaliq A (2000). Efficacy of sorgaab (sorghum water extract) as a natural weed inhibitor in wheat. Int J Agric Biol 2:144-146.

18. Jabeen N \& Ahmed M (2009). Possible allelopathic effects of three different weeds on germination and growth of maize (Zea mays) cultivars. Pakistan J Bot 41: 1677-1683.

19. Ankita G \& Chabbi M (2012). Effect of allelopathic leaf extract of some 
selected weed flora of Ajmer district on seed germination of Triticum aestivum. Sci Res Rept 2: 311-315.

20. Ashraf M \& Akhlaq M (2007). Effects of sorghum leaves, roots and stems water extract, hand weeding and herbicide on weeds suppression and yield of wheat. Sarhad J Agri 23: 321328.

21. Khaliq A, Matloob A, Khan MB \& Tanveer A (2013). Differential suppression of rice weeds by allelopathic plant aqueous extracts. Planta Daninha 31(1): 21-28.

22. Iqbal J \& Cheema ZA (2008). Purple nutsedge (Cyprus rotundus L.) management in cotton with combined application of sorgaab and S.metolachlor. Pakistan J Bot 40 (16): 2383-2391.

23. Mubeen K, Nadeem MA, Tanveer A \& Jhala AJ (2014). Effects of seeding time and weed control methods in direct seeded rice (Oryza Sativa L.). J Anim Plant Sci 24(2): 534-542.

24. Jamil M, Cheema ZA, Mushtaq MN, Farooq M \& Cheema MA (2009). Alternative control of wild oat and canary grass in wheat fields by allelopathic plant water extracts. Agron Sustain Dev 29: 475-482.

25. Khan I, Hassan G, Khan MA \& Khan MI (2003). Efficacy of some new herbicidal molecules on weed density and yield components of wheat. Pakistan J Weed Sci Res 9(4): 141-146.

26. Khan EA, Khakhwani AZ, Munir M \& Ullah G (2015). Effect of allelopathic chemicals extracted from various plant leaves on weed control and wheat crop productivity. Pakistan J Bot 47(2): 735740.

27. Iqbal J, Karim F \& Hussain S (2010). Response of the wheat crop (Triticum aestivum L.) and its weeds to allelopathic crop water extracts in combination with reduced herbicides rates. Pakistan J Agri Sci. 47: 309-316.

28. Cheema ZA, Iqbal $M$ \& Ahmad $R$ (2002). Response of wheat varieties and some Rabbi weeds to allelopathic effects of sorghum water extract. Int $J$ Agri Biol 52-55.

29. Arif M, Cheema ZA, Khaliq A \& Hassan A (2015). Organic weed management in wheat through allelopathy. Int J Agric Biol 17(1): 127134.

30. Elahi M, Cheema ZA, Basra SMA, Akram M \& Ali Q (2011). Use of allelopathic water extract of field crops for weed control in wheat. Int Res $J$ Plant Sci 2(9): 262-270.

31. Awan FK, Rasheed M, Ashraf M \& Khurshid MY (2012). Efficacy of brassica sorghum and sunflower aqueous extracts to control wheat weeds under rainfed conditions of Pothwar. $J$ Anim Plant Sci 22: 715-721. 